\title{
Changes in cultural characteristics and biological activities of amaranth during fermentation
}

\author{
Rea-Hyun Lee, Su-Jin Yang, Joo-Heon Hong* \\ Department of Food Science and Technology, Catholic University of Daegu, Gyeongsan 38430, Korea
}

\section{발효시간에 따른 아마란스 발효물의 배양특성 및 생리활성}

\author{
이래현 · 양수진 · 홍주헌* \\ 대구가톨릭대학교 식품공학전공
}

\begin{abstract}
Bacillus amyloliquefaciens CGD3 was used as a starter for fermentation of amaranth and cultural characteristics and biological activities of amaranth were investigated. The viable cells in fermented amaranth was 4.54 8.01 log CFU/mL during $96 \mathrm{hr}$ of fermentation period. Protease activities of amaranth showed the highest by $36.7 \mathrm{unit} / \mathrm{mL}$ after $72 \mathrm{hr}$ of fermentation. The total phenolic and flavonoid contents of amaranth increased with fermentation time while its total sugar content decreased. The total protein content was the highest in amaranth fermented for $96 \mathrm{hr}(0.25 \mathrm{mg} / \mathrm{g})$. The DPPH scavenging activities, FRAP (feric reducing antioxidant power), and reducing power of amaranth were highest in amaranth fermented for $72 \mathrm{hr}$, showing $84.46 \%, 551.91 \mu \mathrm{M}$, and 2.74, respectively. ACE (angiotensin converting enzyme) and a-Glucosidase inhibition rates increased with fermentation time and showed the highest after $72 \mathrm{hr}$.
\end{abstract}

Key words : Bacillus amyloliquefaciens CGD3, fermented amaranth, protease activity, ACE inhibitory activity, a -glucosidase inhibitory activity

\section{서 론}

최근 생활수준이 향상됨에 따라 현대인들의 식생활은 서구화 되어 동물성 식품 및 고칼로리 인스턴트식품의 섭취 가 증가하고 있다. 이로 인해 건강에 대한 관심이 높아지고 있으며, 건강 증진을 위해 장내 균총을 새롭게 형성하거나 면역계 활성 등을 목적으로 프로바이오틱스(probiotics)라 는 미생물 유래 기능성식품이 소비되고 있다 $(1,2)$. 또한 비 만, 당뇨병 및 고혈압 등의 만성질환 유병률이 증가함에 따라 소비자들은 영양공급이라는 식품고유의 기능 이외에 건강증진과 질병치료 등의 기능을 가진 식품에 대한 관심이 늘어나고 있다 $(3,4)$. 식품공전에서의 효소식품은 식물성 원

*Corresponding author. E-mail : jhhong@cu.ac.kr

Phone : 82-53-850-3218, Fax : 82-53-850-3218

Received 6 April 2016; Revised 3 May 2016; Accepted 11 May 2016.

Copyright (c) The Korean Society of Food Preservation. All rights reserved.
료에 식용 미생물을 배양시켜 효소를 다량 함유하게 하거나 식품에서 효소함유 부분을 추출한 것 또는 이를 원료로 하여 섭취가 용이하도록 가공한 것으로 정의하고 있다. 식 품 유형상 기타 식품류에 속하며 곡류 효소함유 제품, 배아 효소함유 제품, 과채류 효소함유 제품 및 기타 식물 효소 제품으로 분류된다(5).

발효는 미생물을 이용하여 유기물을 분해시키는 과정으 로 유효성분 및 흡수율 증가 등의 효과를 나타내어 다양한 기능성 연구가 활발히 이루어지고 있다(6). 특히, 영양성분 을 그대로 유지하면서 미생물이 분비하는 각종 가수분해효 소와 세포 내 조직에 결합되어 있는 생리활성 물질들이 유리화되면서 생체 이용률을 향상 시켜주는 효과가 있다 (7).

아마란스(Amaranthus ssp L.)는 비름과에 속하는 일년생 식물로 곡물과 비슷하여 아곡류(pseudocereal)로 불려지고 있으며 영양성분을 보면 조단백질은 $17 \sim 18 \%$, 지방은 7 8\% 정도로 옥수수나 밀보다 높으며 섬유소는 비슷하거나 높게 함유하고 있다. 특히 아마란스 단백질은 화곡류에 부족한 
lysine 함량이 단백질 $100 \mathrm{~g}$ 당 $5.2 \mathrm{~g}$ 으로 옥수수 $(3.4 \mathrm{~g})$, 밀 $(3.2 \mathrm{~g})$ 에 비해 높으며, 스쿠알렌, 토코트리에놀, 비 발효성 식이섬유, 인지질, 렉틴 및 기타 항산화 성분 등 다수의 유용한 기능성분을 함유하고 있다(8-10). 이와 같이 아마란 스는 영양 생리학 측면에서 유용 성분을 함유하고 있어 지질대사에 효과가 있으며 또한 아마란스 전분 입자의 크기 는 전분 중 가장 작아 다양한 용도로 이용이 가능하여 제과. 제빵용 혼합분, 국수, 비스켓 등에 혼합하여 사용되고 있다 (11-13).

따라서 본 연구에서는 곡류 효소함유 제품 개발을 위한 소재 탐색의 일환으로 아마란스를 영양원으로 하여 protease를 생산하는 Bacillus amyloliquefaciens CGD3로 발 효하였으며 발효시간에 따른 배양특성과 기능적 특성을 조사하였다.

\section{재료 및 방법}

\section{실험재료}

본 실험에 사용한 아마란스는 원산지가 강원도 평창군인 제품을 농협 하나로마트에서 구입하여 이물질을 제거하고 분쇄기(J-NCM, Jisico, Seoul, Korea)로 분쇄하여 $40 \mathrm{mesh}$ 표준망체를 통과시켜 사용하였다. 아마란스 발효를 위해 사용된 미생물은 청국장으로부터 분리동정하여 보관중인 Bacillus amyloliquefaciens CGD3(KACC92048P) 균주를 이 용하였다.

\section{Starter 배양액 제조}

아마란스 발효물 제조를 위한 starter 배양액은 nutrient broth를 $121^{\circ} \mathrm{C}$ 에서 15 분간 멸균한 액체 배지에 nutrient $\operatorname{agar}$ (Difco, Detroit, MI, USA)로 $37^{\circ} \mathrm{C}$ 에서 24시간 동안 배양 한 B. amyloliquefaciens CGD3를 1회 접종한 뒤, 진탕배양기 에서 $37^{\circ} \mathrm{C}, 24$ 시간 동안 배양하여 starter로 사용하였다.

\section{발효물 제조}

발효시간에 따른 아마란스 발효물 제조를 위해 각각의 아마란스 분말 $20 \mathrm{~g}$ 을 삼각플라스크에 넣고 살균 후 40 $\mathrm{mL}$ 의 멸균수를 가한 다음 미리 배양된 B. amyloliquefaciens $\mathrm{CGD} 3$ starter액을 $2 \%$ 접종 후 $37^{\circ} \mathrm{C}$ 진탕배양기에서 96 시간 까지 발효하였으며, 발효물의 배양적 특성은 배양 시간별 로 측정하였다. 배양이 완료된 발효물은 동결건조 하였으 며, 동결건조 분말은 $-72^{\circ} \mathrm{C}$ 에 보관하면서 실험에 사용하였 다.

\section{생균수 측정}

아마란스 발효물의 생균수 측정은 배양액 $1 \mathrm{~mL}$ 에 $0.85 \%$ sodium chloride(Duksan pure chemicals, Ansan, Korea)용액
$9 \mathrm{~mL}$ 를 혼합하여 10 배 희석법으로 희석한 다음, 각각의 희석액 $100 \mu \mathrm{L}$ 를 nutrient agar(Difco)에 접종하였다. 배양기 에서 $37^{\circ} \mathrm{C}, 24$ 시간 배양한 다음 형성된 colony 수를 계측하 고 colony에 희석배수를 곱하여 시료 $\mathrm{mL}$ 당 colony forming unit(CFU)로 나타내었다.

\section{Protease활성 측정}

Protease 활성은 Kunitz법(14)을 변형하여 측정하였으며, 아마란스 발효물을 원심분리 후 여과한 상등액을 조효소액 으로 사용하였다. 시료 $0.5 \mathrm{~mL}$ 와 $50 \mathrm{mM}$ sodium phosphate 완충용액(pH 7.0)을 이용한 $0.6 \%$ casein 용액(w/v, Duksan pure chemicals) $0.5 \mathrm{~mL}$ 를 가하고 진탕 항온수조(BS-31, Jeio tech, Seoul, Korea)를 이용하여 $37^{\circ} \mathrm{C}, 100 \mathrm{rpm}$ 에서 30 분간 반응시킨 후 $0.44 \mathrm{M}$ trichloroacetic acid(Acros organics, Geel, Belgium) $1 \mathrm{~mL}$ 를 넣어 $37^{\circ} \mathrm{C}$ 에서 30 분간 반응을 중지 시키고 반응액을 원심분리기(1236MG, GYROZEN Co., Daejeon, Korea)를 이용하여 $3,000 \mathrm{rpm}$ 에서 10 분간 원심분 리 하였다. 상등액 $1 \mathrm{~mL}$ 를 취하여 $0.55 \mathrm{M}$ sodium carbonate anhydrous(Duksan pure chemicals) $2.5 \mathrm{~mL}$ 와 $1 / 3$ 희석한 Folin Ciocalteu 용액(Sigma-Aldrich Co., St. Louis, MO, USA) $0.5 \mathrm{~mL}$ 를 가하여 $37^{\circ} \mathrm{C}$ 에서 30 분간 발색반응을 시킨 다음 분광광도계(Ultraspec-2100pro, Amersham Co., Uppsala, Sweden)로 $660 \mathrm{~nm}$ 에서 흡광도를 측정하였다. Protease 활 성은 tyrosine(Sigma-Aldrich Co.)을 정량하여 작성한 표준 곡선으로부터 계산하였으며, 활성단위(unit)는 1 분당 $1 \mu \mathrm{g}$ 의 tyrosine을 생성하는 효소의 양으로 정의하였다.

\section{총 폴리페놀 및 총 플라보노이드 함량}

총 폴리페놀함량 및 총 플라보노이드 함량은 아마란스 발효물 동결건조분말 $0.2 \mathrm{~g}$ 에 증류수 $10 \mathrm{~mL}$ 를 가하여 원심 분리 후 여과한 상등액을 시료로 이용하였다. 총 폴리페놀 함량은 Folin-Denis(15) 방법에 따라 시료 $1 \mathrm{~mL}$ 에 $1 \mathrm{~N}$ Folin-Ciocalteu regent를 혼합하고 $20 \% \mathrm{Na}_{2} \mathrm{CO}_{3} 0.5 \mathrm{~mL}$ 를 첨가하여 실온에서 30 분간 반응시킨 후 분광광도계 (Ultraspec 2100pro, Amersham Co., Uppsala, Sweden)를 이 용하여 $725 \mathrm{~nm}$ 에서 흡광도를 측정하였다. 이 때 총 폴리페 놀 함량은 tannic acid(Sigma-Aldrich Co., St. Louis, MO, USA)를 정량하여 작성한 표준곡선에 의하여 함량을 계산 하였다.

총 플라보노이드함량은 Jimenez 등(16)의 방법을 응용하 여 시료 $100 \mu \mathrm{L}$ 에 $1 \mathrm{~mL}$ diethyl glycol을 혼합하여 실온에서 5 분간 반응 시킨 후 $0.1 \mathrm{~N} \mathrm{NaOH} 200 \mu \mathrm{L}$ 와 혼합하여 $37^{\circ} \mathrm{C}$ 에 서 1시간 반응시키고 $420 \mathrm{~nm}$ 에서 분광광도계로 흡광도를 측정하였다. 총 플라보노이드 함량은 rutin(Sigma-Aldrich Co., St. Louis, MO, USA)을 정량하여 작성한 표준곡선에 의하여 계산하였다. 


\section{총 단백질 및 총 당 함량}

총 단백질 함량 및 총 당 함량은 아마란스 발효물 동결건 조 분말에 증류수를 가하여 원심분리 후 여과한 상등액을 시료로 이용하였다. 총 단백질 함량은 Lowry 등(17)의 방법 으로 측정하였으며 BSA(bovine serum albumin, SigmaAldrich Co., St. Louis, MO, USA)를 정량하여 작성한 표준 곡선으로부터 계산하였다.

총 당 함량 분석은 Saha와 $\operatorname{Brewer(18)}$ 의 방법에 따라 phenol-sulfuric acid법으로 실시하였다. 즉 5\% phenol (w/v) $1 \mathrm{~mL}$ 와 sulfuric acid $5 \mathrm{~mL}$ 를 시료 $1 \mathrm{~mL}$ 와 반응시킨 후 분광광도계(Ultraspec 2100pro, Amersham Co., Uppsala, Sweden)를 사용하여 $525 \mathrm{~nm}$ 에서 흡광도를 측정하고 glucose(Sigma-Aldrich Co., St. Louis, MO, USA)를 정량하 여 작성한 표준곡선으로부터 계산하였다.

\section{유리아미노산분석}

유리아미노산은 시료 $0.2 \mathrm{~g}$ 에 $80 \%$ ethanol $20 \mathrm{~mL}$ 를 가하 여 24 시간 교반한 뒤 원심분리 $(4,000 \times \mathrm{g}, 15$ 분 $)$ 하여 상층액 과 침전물을 분리하였다. 분리된 상층액을 $45^{\circ} \mathrm{C}$ 에서 감압 농축하였으며 농축한 시료는 $0.02 \mathrm{~N} \mathrm{HCI} 3 \mathrm{~mL}$ 로 정용한 후 $0.4 \mu \mathrm{m}$ membrane filter로 여과하여 아미노산 자동분석기 (L-8900, Hitachi Co., Tokyo, Japan)로 분석하였다.

\section{전자공여능}

전자공여능은 $\operatorname{Biois(19)ㅇㅢ~ㅂㅏㅇㅂㅓㅂㅇㅔ~ㄸㅏㄹㅏ~1,1-diphenyl-~}$ 2-picrylhydrazyl(DPPH)의 환원력을 이용하여 측정하였다. 즉, DPPH 용액은 DPPH $12 \mathrm{mg}$ 을 absolute ethanol $100 \mathrm{~mL}$ 에 용해한 후 $\mathrm{dH}_{2} \mathrm{O} 100 \mathrm{~mL}$ 첨가하여 제조하였다. 아마란스 발효물 동결건조 분말을 증류수로 10 배 희석하여 원심분리 한 상등액 시료 $0.5 \mathrm{~mL}$ 에 DPPH reagent $5 \mathrm{~mL}$ 를 혼합하여 실온에서 15 분간 반응시킨 후 분광광도계로 흡광도를 측정 하고 아래와 같이 계산하였다.

$$
\operatorname{EDA}(\%)=\left(1-\frac{\mathrm{S}-\mathrm{SB}}{\mathrm{C}}\right) \times 100
$$

S : absorbance of sample at $517 \mathrm{~nm}$

SB : absorbance of sample blank at $517 \mathrm{~nm}$

C : absorbance of control at $517 \mathrm{~nm}$

\section{FRAP 측정}

FRAP(ferric reducing antioxidant power) 측정은 Benzie와 $\operatorname{Strain}(20)$ 의 방법에 따라 다음과 같이 측정하였다. FRAP reagent는 $25 \mathrm{~mL}$ acetate buffer $(300 \mathrm{mM}, \mathrm{pH} 3.6)$ 를 $37^{\circ} \mathrm{C}$ 에서 가온한 후, $40 \mathrm{mM} \mathrm{HCl}$ 에 용해한 $10 \mathrm{mM}$ 2,4,6-tris(2pyridyl)-s-triazine(TPTZ, Sigma-Aldrich Co., St. Louis, MO, USA) $2.5 \mathrm{~mL}$ 와 $20 \mathrm{mM}$ ferric chloride $\left(\mathrm{FeCl}_{3}\right) 2.5 \mathrm{~mL}$ 를 첨가 하여 제조하였다. 원심분리 한 시료 상등액 $30 \mu \mathrm{L}$ 에 제조된
FRAP reagent $900 \mu \mathrm{L}$ 와 증류수 $90 \mu \mathrm{L}$ 를 넣은 후 $37^{\circ} \mathrm{C}$ 에서 10 분간 반응시킨 후 분광광도계를 이용하여 $510 \mathrm{~nm}$ 에서 흡광도를 측정하였다. $\mathrm{FRAP}$ 는 $\mathrm{FeSO}_{4} \cdot 7 \mathrm{H}_{2} \mathrm{O}$ (Sigma-Aldrich Co., St. Louis, MO, USA)을 정량하여 작성한 표준곡선으로 부터 계산하였다.

\section{환원력 측정}

환원력은 Oyaizu(21)의 방법에 따라 다음과 같이 측정하 였다. 원심분리 한 시료 상등액 $1 \mathrm{~mL}$ 에 $0.2 \mathrm{M}$ phosphate buffer(pH 6.6) $2.5 \mathrm{~mL}$ 와 $1 \%$ potassium ferricyanide 용액 $2.5 \mathrm{~mL}$ 를 가한 후 $50^{\circ} \mathrm{C}$ 에서 30 분간 반응시켰다. 반응 후 $10 \%$ trichloroacetic acid 용액 $2.5 \mathrm{~mL}$ 를 가한 후 원심분리한 뒤, 상등액 $2.5 \mathrm{~mL}$ 에 증류수 $2.5 \mathrm{~mL}$ 와 $0.1 \% \mathrm{FeCl}_{3}$ 용액 0.5 $\mathrm{mL}$ 를 가한 후 분광광도계를 이용하여 $700 \mathrm{~nm}$ 에서 흡광도 를 측정하였다.

\section{a-Glucosidase 저해활성}

a-Glucosidase 저해활성은 Watanabe 등(22)의 방법에 따 라 측정하였다. 원심분리 한 시료상등액 $60 \mu \mathrm{L}$ 에 0.2 unit/mL a-glucosidase 효소액 $50 \mu \mathrm{L}, 0.1 \mathrm{M}$ potassium phosphate buffer(pH 6.8) $50 \mu \mathrm{L}$ 를 혼합하여 $37^{\circ} \mathrm{C}$ 에서 20 분 동안 전배양 한 후 $3 \mathrm{mM}$ p-nitrophenyl a-D-glucopyranoside ( $\mathrm{NNPG}) 50 \mu \mathrm{L}$ 를 첨가한 다음 $37^{\circ} \mathrm{C}$ 에서 20 분간 반응시키고 $0.1 \mathrm{M}$ sodium carbonate $500 \mu \mathrm{L}$ 로 반응을 정지시켰다. 405 $\mathrm{nm}$ 에서 흡광도를 측정하고 시료용액과 동량의 완충용액을 넣은 대조군을 기준으로 효소 저해활성을 아래의 식으로 계산하였다.

a-Glucosidase inhibition rate $(\%)=\left(1-\frac{\mathrm{S}-\mathrm{SB}}{\mathrm{C}}\right) \times 100$

S : absorbance of sample at $405 \mathrm{~nm}$

SB : absorbance of sample blank at $405 \mathrm{~nm}$

C : absorbance of control at $405 \mathrm{~nm}$

\section{$\mathrm{ACE}$ 저해활성}

$\mathrm{ACE}$ (angiotensin converting enzyme) 저해활성은 Cushman 와 Cheung(23)의 방법을 일부 변형하여 측정하였다. 조효소 액은 rabbit lung acetone powder(Sigma-Aldrich Co., St. Louis, MO, USA)를 $0.3 \mathrm{M} \mathrm{NaCl}$ 을 함유한 $0.1 \mathrm{M}$ sodium borate buffer(pH 8.3)에 $1 \mathrm{~g} / 10 \mathrm{~mL}$ (w/v)의 농도로 $4^{\circ} \mathrm{C}$ 에서 24 시간 추출한 다음, $4^{\circ} \mathrm{C}, 10,000 \mathrm{rpm}$ 으로 30 분간 원심 분리 하여 상등액을 $\mathrm{ACE}$ 조효소액으로 사용하였다. 기질은 0.3 $\mathrm{M} \mathrm{NaCl}$ 을 함유한 $0.1 \mathrm{M}$ sodium borate buffer(pH 8.3)에 $12.5 \mathrm{mM}$ HHL(hippuril-L-histhdine-L-leucine, Sigma-Aldrich Co., St. Louis, MO, USA)로 녹여 기질로 사용하였다. ACE 저해활성은 원심분리한 시료 상등액 $10 \mu \mathrm{L}$ 와 $0.1 \mathrm{M}$ sodium borate buffer( $\mathrm{pH}$ 8.3) $45 \mu \mathrm{L}$ 에 기질을 $100 \mu \mathrm{L}$ 첨가한 후, 
$37^{\circ} \mathrm{C}$ 에서 30 분간 반응시켰다. 반응 후 $1 \mathrm{~N} \mathrm{HCI} 250 \mu \mathrm{L}$ 를 사용하여 반응을 정지시키고 ethyl acetate $1.5 \mathrm{~mL}$ 를 가하여 30 초간 교반하여 $3,000 \mathrm{rpm}$ 으로 5 분간 원심분리 한 후 상등 액 $1 \mathrm{~mL}$ 를 취하였다. 이 상등액을 $120^{\circ} \mathrm{C}$ 에서 완전히 건조 시킨 후 증류수 $1 \mathrm{~mL}$ 를 넣어 용해시키고 $228 \mathrm{~nm}$ 에서 흡광 도를 측정하였다. 이때 $\mathrm{ACE}$ 저해활성은 시료첨가구와 무 첨가구의 흡광도 차이를 비교하여 백분율로 나타내었다.

ACE inhibitory activity $(\%)=\left(1-\frac{\mathrm{S}-\mathrm{SB}}{\mathrm{C}}\right) \times 100$

S : absorbance of sample at $228 \mathrm{~nm}$

SB : absorbance of sample blank at $228 \mathrm{~nm}$

C : absorbance of control at $228 \mathrm{~nm}$

\section{통계처리}

실험 결과는 3회 반복 측정 후 평균 \pm 표준편차로 나타내 었으며, SPSS 19.0을 이용하여 각 시료간의 유의성을 검증 한 후 $\mathrm{p}<0.05$ 수준에서 Duncan's multiple range test에 따라 분석하였다.

\section{결과 및 고찰}

\section{생균수 및 protease 활성}

청국장으로부터 분리된 B. amyloliquefaciens 중 우수한 protease 활성을 가지는 B. amyloliquefaciens CGD3를 이용 하여 아마란스 분말을 발효한 다음 미생물 생장에 미치는 영향을 검토하기 위하여 96시간 발효 후 배양시간별 생균 수 및 protease 활성을 측정한 결과는 Fig. 1과 같다. 아마란 스 발효물의 생균수는 초기 0시간에서 $4.54 \log \mathrm{CFU} / \mathrm{mL}$ 였 으며, 발효 12 시간 이후에는 $7.01 \log \mathrm{CFU} / \mathrm{mL}$ 수준으로

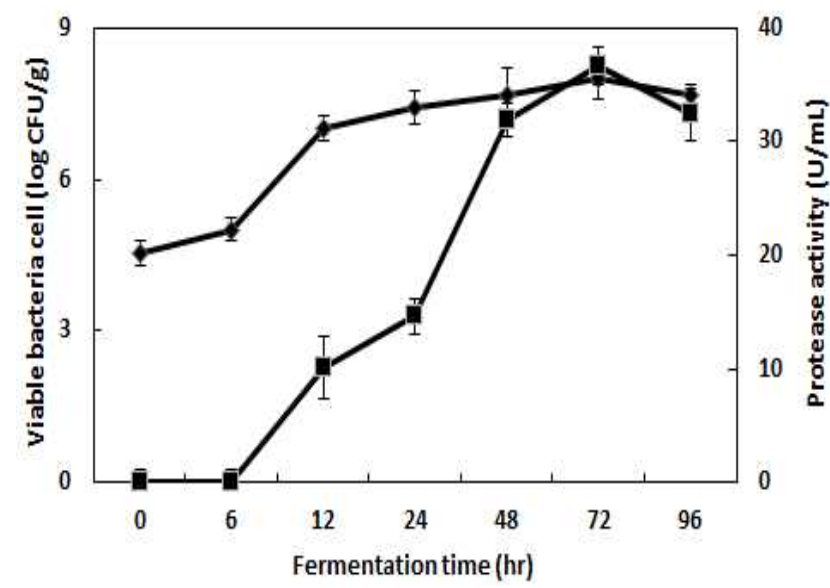

Fig. 1. Growth curve and protease activity of fermented amaranth according to fermentation time.

, Viable bacteria cell; $\mathbf{\square}$, Protease activity. The data are expressed the means $\pm \mathrm{SD}(\mathrm{n}=3)$.
0시간에 비해 $2 \log$ 이상 증가하였고 그 이후 발효시간에 따라 증가하여 72 시간에서 $8.01 \log \mathrm{CFU} / \mathrm{mL}$ 로 가장 높게 나타났다. Yang 등(24)의 연구에서 B. subtilis CBD2를 이용 한 곡류 발효물의 배양특성에서 미생물들이 곡류를 자기 증식에 효과적으로 이용함에 따라 96시간 발효하였을 때 $6.89 \log \mathrm{CFU} / \mathrm{mL}$ 로 생균수가 증가하였다고 보고하여 본 연구결과와 유사하였다. 또한, 0 6시간 아마란스 발효물의 protease 활성은 측정되지 않았으며, 12 96시간 발효 시 $10.12 ~ 36.70 \mathrm{unit} / \mathrm{mL}$ 증가하여 72시간 배양하였을 때 최대 로 높은 protease 활성을 나타내었고 이후부터는 감소하는 경향을 보였다.

\section{총 폴리페놀 및 총 플라보노이드 함량}

아마란스 발효물의 총 폴리페놀 및 총 플라보노이드 함 량은 Table 1과 같다. 총 폴리페놀 함량은 0시간에서 412.14 $\mathrm{mg} / 100 \mathrm{~g}$ 으로 나타났으며, 12 시간 이상 발효하였을 때 $558.90 \mathrm{mg} / 100 \mathrm{~g}$ 으로 0시간에서 보다 총 폴리페놀 함량이 $35.61 \%$ 증가하였다. 발효시간이 증가할수록 총 폴리페놀 함량은 유의적으로 증가하는 경향을 나타냈으며, 96시간 발효하였을 때 $582.07 \mathrm{mg} / 100 \mathrm{~g}$ 함량을 나타내었다. 아마란 스 발효물의 총 플라보노이드 함량은 아마란스 0 시간에서 $180.56 \mathrm{mg} / 100 \mathrm{~g}$ 이었으며 발효 6시간까지는 유지되다가 12 시간 발효하였을 때 $254.95 \mathrm{mg} / 100 \mathrm{~g}$ 으로 발효 초기에 비해 $40.38 \%$ 증가하였다. 발효시간이 증가할수록 유의적 으로 증가하는 총 폴리페놀 함량 변화와 유사한 경향이었으 며, 총 폴리페놀 및 플라보노이드는 72 시간 발효 하였을 때 각각 $627.99 \mathrm{mg} / 100 \mathrm{~g}$ 및 $442.32 \mathrm{mg} / 100 \mathrm{~g}$ 으로 가장 높은 함량을 나타내었다. 이는 발효과정 중에 미생물 또는 가열반응에 의해 phenol ethyl 유도체 및 vinyl 유도체가 생성되어 폴리페놀 및 플라보노이드 함량이 증가한다는 연구(25)와 유사한 경향을 나타내었다.

Table 1. Total polyphenol and total flavonoid contents of fermented amaranth according to fermentation time

\begin{tabular}{ccc}
\hline $\begin{array}{c}\text { Fermentation } \\
\text { time (hr) }\end{array}$ & $\begin{array}{c}\text { Total polyphenol content } \\
(\mathrm{mg} / 100 \mathrm{~g})\end{array}$ & $\begin{array}{c}\text { Total flavonoid content } \\
(\mathrm{mg} / 100 \mathrm{~g})\end{array}$ \\
\hline 0 & $412.14 \pm 1.89^{\mathrm{fl}} \mathrm{c}$ & $180.56 \pm 8.43^{\mathrm{f}}$ \\
6 & $428.59 \pm 4.60^{\mathrm{f}}$ & $181.61 \pm 0.80^{\mathrm{f}}$ \\
12 & $558.90 \pm 6.03^{\mathrm{e}}$ & $254.95 \pm 4.11^{\mathrm{e}}$ \\
24 & $601.12 \pm 3.74^{\mathrm{c}}$ & $345.47 \pm 4.32^{\mathrm{d}}$ \\
48 & $613.52 \pm 4.91^{\mathrm{ab}}$ & $411.79 \pm 8.17^{\mathrm{c}}$ \\
72 & $627.99 \pm 3.72^{\mathrm{a}}$ & $442.32 \pm 7.37^{\mathrm{f}}$ \\
96 & $582.07 \pm 7.24^{\mathrm{d}}$ & $435.12 \pm 4.75^{\mathrm{a}}$ \\
\hline
\end{tabular}

${ }^{1)}$ All values are mean \pm SD $(n=3)$. Means with different superscripts (a-f) within the same column are significantly different $(\mathrm{p}<0.05)$. 


\section{총 단백질 및 총 당 함량}

아마란스 발효물의 총 단백질 및 총당 함량은 Table 2 와 같다. 0 시간 구간에서 $0.09 \mathrm{~g} / 100 \mathrm{~g}$ 의 단백질 함량을 나타내 었고 아마란스 발효 시간이 증가할수록 단백질 함량이 높아 지는 경향을 보였으며 96시간 아마란스 발효 시 $0.25 \mathrm{~g} / 100$ $\mathrm{g}$ 으로 가장 높은 함량을 나타내었다. 이는 $\mathrm{Ahn}$ 등(26)이 비 발효 동충하초 분말보다 발효 동충하초 분말에서 단백질 농도가 약 2배 높게 나타났으며, Bacillus, Aspergillus와 같 은 미생물 유래 단백질 분해효소 분비에 의해 단백질 함량 이 증가하였다고 보고되어 본 연구에서도 protease 생산 균주인 B. amyloliquefaciens CGD3를 이용하여 발효함으로 써 단백질 함량이 증가 한 것이라 사료된다.

총 당 함량은 0시간에서 $2,816.67 \mathrm{mg} / 100 \mathrm{~g}$ 이었고 아마란 스 분말을 24 시간 발효하였을 때 $2,102.73 \mathrm{mg} / 100 \mathrm{~g}$ 으로 0 시간에서 보다 $33.95 \%$ 감소하였고, 48 시간 발효 시 당 함량 이 $1,643.31 \mathrm{mg} / 100 \mathrm{~g}$ 까지 감소하였으며 48시간 발효 시간 이후에는 급격한 감소는 관찰되지 않았다. 이는 발효 중 환원당이 미생물의 작용으로 lactic acid, acetic acid 및 그 외 여러 물질들로 변하거나 미생물이 당을 분해해서 에너지 원으로 이용함으로써 환원당 함량이 감소한다는 보고 $(27,28)$ 와 유사한 경향을 보였으며, 본 연구에서 아마란스 를 시간별 발효과정을 거치면서 저분자의 단당류나 이당류 를 에너지원으로 이용한 것으로 사료된다.

Table 2. Total sugar and total protein contents of fermented amaranth according to fermentation time

\begin{tabular}{ccc}
\hline $\begin{array}{c}\text { Fermentation time } \\
(\mathrm{hr})\end{array}$ & $\begin{array}{c}\text { Total protein content } \\
(\mathrm{g} / 100 \mathrm{~g})\end{array}$ & $\begin{array}{c}\text { Total sugar content } \\
(\mathrm{mg} / 100 \mathrm{~g})\end{array}$ \\
\hline 0 & $0.09^{\mathrm{g} 1)}$ & $2,816 \pm 61^{\mathrm{a}}$ \\
6 & $0.10^{\mathrm{f}}$ & $2,859 \pm 30^{\mathrm{a}}$ \\
12 & $0.14^{\mathrm{e}}$ & $2,918 \pm 63^{\mathrm{a}}$ \\
24 & $0.18^{\mathrm{d}}$ & $2,102 \pm 44^{\mathrm{b}}$ \\
48 & $0.21^{\mathrm{c}}$ & $1,643 \pm 22^{\mathrm{c}}$ \\
72 & $0.23^{\mathrm{b}}$ & $1,554 \pm 21^{\mathrm{d}}$ \\
96 & $0.25^{\mathrm{a}}$ & $1,493 \pm 41^{\mathrm{d}}$ \\
\hline
\end{tabular}

${ }^{11}$ All values are mean $\pm \mathrm{SD}(\mathrm{n}=3)$. Means with different superscripts $(\mathrm{a}-\mathrm{g})$ within the same column are significantly different $(\mathrm{p}<0.05)$.

\section{유리아미노산 함량}

아마란스는 균형잡힌 아미노산을 구성하고 있어 bioactive properties가 높아 다양하게 이용될 수 있는 새로운 곡물로 인식되고 있다(29). 아마란스를 발효함으로써 변화하는 유 리아미노산을 확인하고자 발효시간에 따른 아마란스 발효 물의 유리아미노산을 분석 하여 Table 3 에 나타내었다. 실 험구 0시간에서의 유리아미노산 함량은 $119.49 \mathrm{mg} / 100 \mathrm{~g}$ 이 었으며 그 중 필수아미노산 함량은 $62.49 \mathrm{mg} / 100 \mathrm{~g}$ 으로 총 유리아미노산의 $52.30 \%$ 를 차지하였다. 발효시간이 증
가함에 따라 유리아미노산 함량은 증가하는 경향을 나타내 었다. 또한 96시간 아마란스 발효물에서 유리아미노산 함 량은 $886.94 \mathrm{mg} / 100 \mathrm{~g}$ 으로 가장 높은 함량을 나타내었으며 필수아미노산 함량은 $517.54 \mathrm{mg} / 100 \mathrm{~g}$ 으로 유리아미노산 함량의 $58.35 \%$ 를 차지하였다. 발효 후 유리아미노산 중 leucine이 $126.67 \mathrm{mg} / 100 \mathrm{~g}$ 으로 가장 높게 나타내었고, valine $102.37 \mathrm{mg} / 100 \mathrm{~g}$, phenylalanine $94.27 \mathrm{mg} / 100 \mathrm{~g}$, isoleucine $70.02 \mathrm{mg} / 100 \mathrm{~g}$ 등의 함량 순이었다. Kim 등(30) 은 볏짚을 이용하여 제조한 청국장 발효제품의 유리아미노 산 함량이 원료콩의 것보다 많았다고 보고하여 본 실험과 유사한 경향을 나타내었으며, 아마란스 또한 발효를 통해 유리아미노산 함량이 증가한 것으로 사료된다. 식품으로 섭취된 단백질 등의 아미노산은 흡수된 후 생체 단백질을 합성하는 재료가 되는데 생체 단백질은 20 여종이 일정한 순서에 따라 결합 및 합성되므로 그 중 1 종류의 아미노산 이라도 부족하면 생체 단백질은 합성될 수 없다. 특히

Table 3. Free amino acid contents of fermented amaranth according to fermentation time

(unit: $\mathrm{mg} / 100 \mathrm{~g}$ )

\begin{tabular}{|c|c|c|c|c|c|c|c|}
\hline \multirow{2}{*}{ Free amino acid } & \multicolumn{7}{|c|}{ Fermentation time (hr) } \\
\hline & 0 & 6 & 12 & 24 & 48 & 72 & 96 \\
\hline Taurine & 4.13 & 4.86 & 4.47 & 4.19 & 4.56 & 4.48 & 4.83 \\
\hline Urea & 0.00 & 0.00 & 0.00 & 0.00 & 0.00 & 56.23 & 52.20 \\
\hline Threonine & 6.17 & 8.21 & 8.25 & 11.77 & 14.20 & 23.75 & 26.10 \\
\hline Glutamic acid & 5.97 & 4.89 & 14.62 & 25.25 & 25.68 & 29.47 & 33.21 \\
\hline Glycine & 3.20 & 4.98 & 5.37 & 7.56 & 7.61 & 9.23 & 11.20 \\
\hline Alanine & 9.15 & 17.35 & 17.32 & 18.04 & 21.99 & 59.14 & 47.68 \\
\hline Citrulline & 0.40 & 0.43 & 1.07 & 2.72 & 3.75 & 3.67 & 9.20 \\
\hline Valine & 14.75 & 15.03 & 16.47 & 36.62 & 42.05 & 45.99 & 102.37 \\
\hline Methionine & 4.19 & 4.28 & 8.30 & 23.07 & 28.05 & 38.72 & 63.57 \\
\hline Isoleucine & 12.30 & 12.79 & 12.69 & 24.07 & 29.43 & 56.63 & 70.02 \\
\hline Leucine & 9.41 & 9.56 & 12.88 & 35.85 & 66.84 & 93.85 & 126.67 \\
\hline Tyrosine & 9.07 & 9.30 & 10.23 & 22.72 & 28.52 & 40.83 & 69.76 \\
\hline Phenylalanine & 8.99 & 9.04 & 11.32 & 31.75 & 36.95 & 60.94 & 94.27 \\
\hline B-Alanine & 6.37 & 6.75 & 1.45 & 1.24 & 1.01 & 1.52 & 5.91 \\
\hline ४-Amino-n-butyric acid & 14.52 & 14.65 & 14.81 & 14.09 & 13.04 & 14.44 & 14.60 \\
\hline Ethanolamine & 3.49 & 3.71 & 4.00 & 2.85 & 2.77 & 2.13 & 2.04 \\
\hline$\delta$-Hydroxylysine & 0.19 & 0.30 & 0.34 & 0.43 & 0.44 & 0.45 & 0.48 \\
\hline Ornithine & 0.51 & 0.47 & 3.30 & 13.39 & 11.98 & 16.97 & 22.29 \\
\hline Lysine & 4.23 & 4.13 & 5.08 & 12.43 & 13.83 & 12.72 & 21.21 \\
\hline Histidine & 2.45 & 1.96 & 2.58 & 5.76 & 6.95 & 6.18 & 13.33 \\
\hline Arginine & 12.30 & 12.31 & 12.19 & 21.65 & 23.84 & 26.35 & 26.59 \\
\hline Total amino acid & 117.04 & 136.73 & 163.97 & 312.04 & 400.7 & 643.16 & 873.61 \\
\hline Total EAA ${ }^{1)}$ & 62.49 & 65.00 & 77.57 & 181.32 & 238.3 & 338.78 & 517.54 \\
\hline
\end{tabular}

${ }^{1)}$ EAA, Essential amino acid (Thr+Val+Met+Ile+Leu+Phe+Lys+His). 
isoleucine, leucine, lysine, phenylalanine, methionine, threonine, tryptophan, valine 등의 아미노산은 인간의 체내에서 합성 되지 않거나 합성되어도 수요량을 충족시키지 못하는 필수 아미노산으로 음식물을 통해서 필요량을 공급해 주어야만 하는 아미노산이다. 본 연구에서는 발효를 통해 필수아미 노산의 함량이 상당히 증가하여 아마란스 발효물을 식품소 재로 이용할 경우 영양학적 가치가 높을 것으로 판단된다.

\section{항산화 활성}

아마란스 발효물의 전자공여능, FRAP 및 환원력은 Table 4에 나타내었다. 전자공여능을 분석한 결과 발효시간 이 증가함에 따라 전자공여능이 증가하였으며 아마란스 72 시간 발효물이 $84.46 \%$ 로 가장 높은 활성을 나타내었다. 이는 발효 전에 비해 $29 \%$ 정도 증가하였고 양성대조군인 ascorbic acid와 유사한 전자공여능을 나타내었다. FRAP를 분석한 결과 실험구 0시간에서 $325.10 \mu \mathrm{M}$ 으로 가장 낮은 활성을 나타내었고 72시간 발효물에서 $551.91 \mu \mathrm{M}$ 로 가장 높은 FRAP 함량을 나타내었다. 환원력을 분석한 결과 아마 란스의 발효가 진행되지 않은 0시간에서 2.07 로 가장 낮은 환원력을 나타내었고 72 시간 발효물이 2.74로 가장 높은 환원력을 나타내었다. $\mathrm{Kim}$ 등(31)은 발효 미생물에 따른 포도가공 부산물의 항산화 활성을 나타낸 결과에서도 발효 한 포도박이 발효하지 않은 포도박의 대조군에 비해 높은 활성을 나타내었다고 보고하였는데, 이는 폴리페놀 화합물 함량과 관련이 있다고 보고하였다. $\mathrm{Kang}$ 와 $\mathrm{Kim}(32)$ 은 phenolic acid의 일종인 caffeic acid, p-courmaric acid 등과 flavonoid 일종인 catechin, quercetin, catechol 및 chlorogenic acid를 포함한 기타 페놀성 물질이 전자공여능에 관여하는 것으로 보고하여 본 연구에서 발효시간에 따른 항산화 활성 의 증가는 발효시간에 따라 phenolic acid와 flavonoid 함량 의 증가로 인한 것으로 사료된다.

\section{a-Glucosidase 및 ACE 저해활성}

식품으로부터 섭취한 다당류는 a-amylase에 의해 이당류

Table 4. DPPH radical scavenging activity, ferric reducing antioxidant power and reducing powder of fermented amaranth according to fermentation time

\begin{tabular}{cccc}
\hline Fermentation time (hr) & DPPH $(\%)$ & FRAP $(\mu \mathrm{M})$ & Reducing power \\
\hline 0 & $54.32 \pm 1.56^{\mathrm{d} 1)}$ & $325.10 \pm 6.36^{\mathrm{d}}$ & $2.07 \pm 0.01^{\mathrm{c}}$ \\
6 & $55.70 \pm 1.71^{\mathrm{d}}$ & $328.06 \pm 6.30^{\mathrm{d}}$ & $2.34 \pm 0.09^{\mathrm{b}}$ \\
12 & $53.721 .72 \pm^{\mathrm{d}}$ & $434.58 \pm 8.51^{\mathrm{c}}$ & $2.42 \pm 0.04^{\mathrm{b}}$ \\
24 & $65.13 \pm 0.90^{\mathrm{c}}$ & $508.90 \pm 5.75^{\mathrm{b}}$ & $2.64 \pm 0.03^{\mathrm{a}}$ \\
48 & $71.63 \pm 1.02^{\mathrm{b}}$ & $515.51 \pm 4.94^{\mathrm{ab}}$ & $2.70 \pm 0.06^{\mathrm{a}}$ \\
72 & $84.46 \pm 0.43^{\mathrm{a}}$ & $551.91 \pm 8.16^{\mathrm{a}}$ & $2.74 \pm 0.08^{\mathrm{a}}$ \\
96 & $73.12 \pm 0.36^{\mathrm{b}}$ & $510.93 \pm 6.49^{\mathrm{ab}}$ & $2.69 \pm 0.04^{\mathrm{a}}$ \\
\hline
\end{tabular}

${ }^{10}$ All values are mean $\pm \mathrm{SD}(\mathrm{n}=3)$. Means with different superscripts (a-d) within the same column are significantly different $(\mathrm{p}<0.05)$.
로 분해되고, 최종적으로 a-glucosidase가 이당류를 단당류 로 분해함으로써 소장의 융털로 흡수된 후 혈관으로 이동되 므로, 이당류 분해 효소인 a-glucosidase의 저해활성은 당질 가수분해와 흡수를 지연시켜 식후 혈당농도가 급격하게 증가되는 것을 억제한다고 보고되고 있다(33). 본 연구에서 는 아마란스 발효시간에 따른 발효물의 a-glucosidase 저해 활성을 Fig. 2에 나타내었다. 아마란스를 0 72시간 발효하 였을 때 a-glucosidase 저해활성이 유의적으로 증가하다가 72 시간 발효 시 $81.41 \%$ 로 가장 높은 저해활성을 나타내었 으며, 발효 96시간부터 감소하는 경향을 보였다.

$\mathrm{ACE}$ (angiotensin coverting enzyme)는 renin에 의하여 생 성된 angiotensin I으로부터 C- 말단 dipeptide(His- Leu)를 가수분해 시킴으로써 강력한 혈관수축작용을 나타내는 angiotensin $\Pi$ 를 생성한다. Angiotensin $\Pi$ 는 결과적으로 혈압을 상승시키므로, $\mathrm{ACE}$ 활성 저해를 통하여 혈관벽의 파괴나 뇌졸중 등의 질환 발생을 억제 할 수 있다. 본 연구에

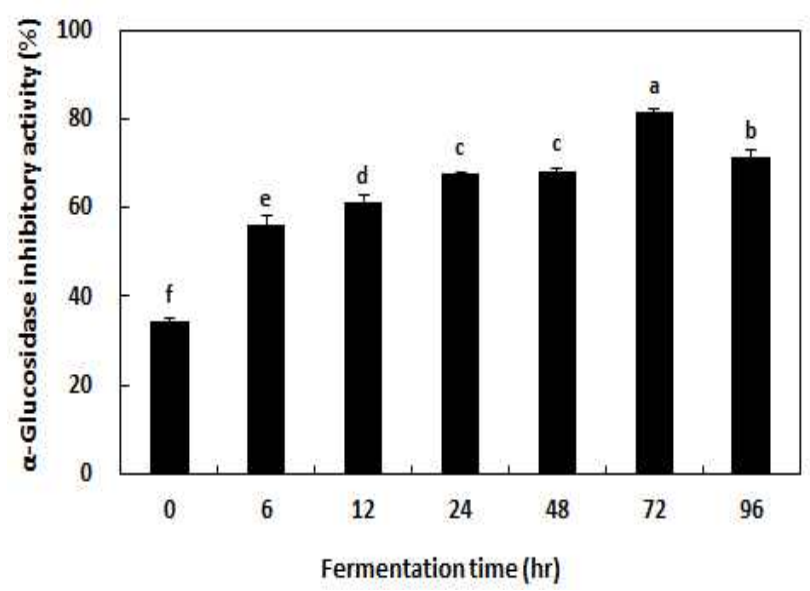

(A)

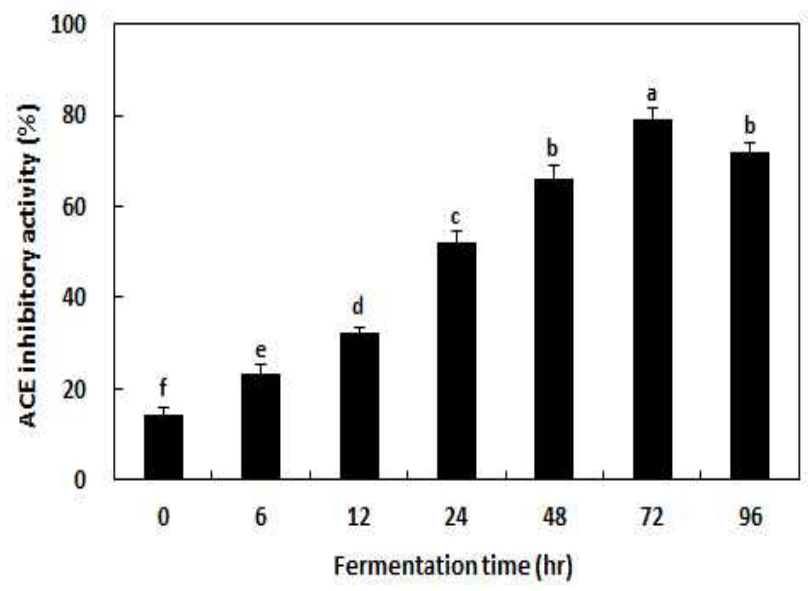

(B)

Fig. 2. a-Glucosidase (A) and ACE (Angiotensin converting enzyme) inhibitory activities (B) of fermented amaranth according to fermentation time.

Means \pm SD ( $n=3$ ) with different letters above a bar are significantly different by Duncan's multiple range test $(\mathrm{p}<0.05)$. 
서는 protease 생산 균주인 B. amyloliquefaciens CGD3를 아마란스에 접종하여 발효시간에 따른 발효물의 $\mathrm{ACE}$ 저해 활성을 측정한 결과 발효시간이 증가할수록 $\mathrm{ACE}$ 저해활성 이 증가하는 경향을 보였으며 72 시간 발효하였을 때 발효 하기 전보다 5 배 이상 증가하여 $79.09 \%$ 의 높은 저해활성을 보였다(Fig. 2). Jung 등(34)의 연구 결과, 발효시간이 길어짐 에 따라 높은 $\mathrm{ACE}$ 저해활성이 나타냈는데 본 연구와 일치 하는 경향을 나타내었다. 일반적으로 대두 등 일부 식품 성분 중의 단백질이 protease에 의해 가수 분해되어 유용 펩타이드를 생성시킴에 따라 $\mathrm{ACE}$ 저해활성을 나타낸다고 보고(35)되어 본 연구에서도 단백질이 가수분해되면서 발 효시간에 따라 $\mathrm{ACE}$ 저해활성이 증가한 것으로 사료된다.

\section{요 약}

청국장으로부터 분리된 B. amyloliquefaciens CGD3를 이 용하여 아마란스를 발효하였으며 발효시간에 따른 발효물 의 이화학적 특성 및 생리활성을 조사하였다. 아마란스 발 효 0시간에서의 생균수는 $4.54 \log \mathrm{CFU} / \mathrm{mL}$ 로 나타났으며 72시간 발효물에서 $8.01 \log \mathrm{CFU} / \mathrm{mL}$ 로 가장 높은 생균수를 나타내었고, protease 활성은 72 시간 배양하였을 때 36.70 unit $/ \mathrm{mL}$ 로 가장 높았다. 총 폴리페놀 및 총 플라보노이드 함량은 발효시간이 증가함에 따라 증가하여 72 시간 발효 시 각각 $601.12 \mathrm{mg} / 100 \mathrm{~g}$ 및 $442.32 \mathrm{mg} / 100 \mathrm{~g}$ 으로 가장 높았으며 72시간 이후부터 감소하는 경향을 보였다. 총 단 백질 함량은 발효시간이 증가할수록 증가하여 96 시간 발효 시 0 시간 보다 2.7배 단백질 함량이 증가하였으며, 총 당 함량은 발효 12 시간 이후부터 급격히 감소하는 경향을 보 였다. 유리아미노산 함량은 발효시간이 증가할수록 증가하 였는데 0시간에서 $119.49 \mathrm{mg} / 100 \mathrm{~g}$ 이었고 96시간 발효시 $886.94 \mathrm{mg} / 100 \mathrm{~g}$ 으로 증가하였다. 전자공여능, FRAP 및 환원력은 72 시간 발효구간에서 각각 $84.46 \%, 551.91 \mu \mathrm{M}$ 및 2.74로 가장 항산화활성이 우수하였다. a-glucosidase 저 해활성 및 $\mathrm{ACE}$ 저해활성은 발효 72시간 구간에서 각각 $81.41 \%$ 및 $79.09 \%$ 의 저해활성을 나타내어 발효최적 시간 임을 확인하였다.

\section{감사의 글}

본 연구는 교육부와 한국연구재단의 지역혁신창의인력 양성사업으로 수행된 연구결과임(No.2013H1B8A2032215).

\section{References}

1. FAO/WHO (2002) Joint FAO/WHO (Food and Agriculture
Organization/World Health Organization) working group report on drafting guidelines for the evaluation of probiotics in food, London, Ontario, Canada

2. Homma N (1998) Bifidobacteria as a resistance factor in human beings. Biosci Microflora, 7, 35-43

3. Lee NY (2013) Antioxidant effect and tyrosinase inhibition activity of seaweeds ethanol extracts. J Korean Soc Food Nutr, 42, 1893-1898

4. Kim SS, Kim SY, Lee WJ (1998) Microwave vacuum drying of germinated brown rice as a potential raw material for enzyme food. Korean J Food Sci Technol, 30, 1107-1113

5. KFDA (2010) Food Code. Korea Food and Drug Administration, Seoul, Korea, 239-240

6. Shin S, Park SS, Lee HM, Hur JM (2014) Effects of fermented chicory fiber on the improvement of intestinal function and constipation. J Korean Soc Food Sci Nutr, 43, 55-59

7. Seo JS, Kim YC, Hong JH (2014) Effect of meju shapes and strains on the chemical composition of soybean paste. J Korean Soc Food Sci Nutr, 15, 1-9

8. Lee JH, Kim KJ, Lee JI, Lee ST, Ryu SN (1996) Functional ingredient and their some variance in amaranth and quinoa. Korean J Crop Sci, 41, 145-165

9. He HP, Cai Y, Sun M, Corke H (2002) Extraction and purification of squalene from Amaranthus grain. J Agric Food Chem, 50, 368-372

10. Lee JH, Moon HI, Lee JI, Kang CW, Lee ST (1996) Isolation and identification of squalene and antineoplastic activity of its residue extract in amaranth. Korean J Crop Sci, 41, 450-455

11. Choi CR, Choi HJ, Kim SR, Lee JH, Shin MS (2000) Comparison of characteristics of amaranth starches isolated from five cultivars grown in Korea. Korean $\mathbf{J}$ Food Sci Technol, 32, 252-257

12. Kim JS, Ryoo HJ (2002) Application to the biscuits manufacture of processed amaranth seeds. Korean J Food Nutr, 15, 321-325

13. Choi HS (2011) Effect of adding amaranth powder on noodle quality. Korean J Food Nutr, 4, 664-669

14. Kunitz M (1947) Crystalline soybean trypsin inhibitor II. General properties. J Gen Physiol, 30, 291-310

15. singleton VL, Rossi JA (1965) Colorimetry of total phenolics with phosphomolybdic-phosphotungstic acid reagents. Am J Enol Vitic, 16, 144-158

16. Jimenez-Aguilar DM, Ortega-Regules AE, Lozada-Ramirez JD, Perez MCI, Vernon-Carter EJ, Welti-Chanes J (2011) 
Color and chemical stability of spray-dried blueberry extract using mesquite gum as wall material. $\mathrm{J}$ food comp anal, 24, 889-894

17. Lowry OH, Rosenbrough NJ, Farr A, Randall RJ (1951) Protein measurement with the Folin phenol reagent. J Biol Chem, 193, 265-275

18. Saha AK, Brewer CF (1994) Determination of the concentrations of oligosaccharides, complex type carbohydrates, and glycoproteins using the phenolsulfuric acid method. Carbohydr Res, 254, 157-167

19. Biois MS (1958) Antioxidant determinations by the use of a stable free radical. nature, 181, 1199-1200

20. Benzie IFF, Strain JJ (1996) The ferric reducing ability of plasma (FRAP) as a measure of antioxidant power: the FRAP assay. Anal Biochem, 239, 70-76

21. Oyaizu M (1986) Studies on products of browning reaction-antioxidative activities of products of browning reaction prepared from glucosamine. Jap J Nutr, 44, 307-315

22. Watanabe J, Kawabata J, Kurihara H, Niki R (1997) Isolation and identification of alpha-glucosidase inhibitors from tochu-cha (Eucommia ulmoides). Biosci biotech biochem, 61, 177-178

23. Cushman DW, Cheung HS (1971) Spectrophotometric assay and properties of the angiotensin-converting enzyme of rabbit lung. Biochem Pharmacol, 20, 1637-1648

24. Yang SJ, Lee DH, Park HM, Jung HK, Park CS, Hong JH (2014) Amylase activity and characterization of Bacillus subtilis CBD2 isolated from Doenjang. Korean J Food Preserv, 21, 286-293

25. Uda Y, Osawa Y, Takayama M, Suzuki K, Maeda Y (1988) Free and soluble bound phenolic acids in some cruciferous vegetables. Nippon Shokuhin Kogyo Gakkaishi 35, 360-366

26. Ahn HY, Park KR, Kim YR, Cha JY, Cho YS (2013) Chemical Characteristics in Fermented Cordycepin- enriched Cordyceps militaris. J Life Sci, 23, 1032-1040

27. Cho Y, Lee HS (1991) Effect of lactic acid bacteria and temperature on kimchi fermentation. Korean J Food Cook Sci, 7, 89-95

28. Yi JH, Cho Y, Hwang IK (1998) Fermentative characteristics of Kimchi prepared by addition of different kinds of minor ingredients. Korean J Food Cook Sci, $14,1-8$

29. Asao M, Wantanabe K (2010) Functional and bioactive properties of quinoa and amaranth. Food Sci Technol Res, 16, 163-168

30. Kim KJ, Ryu MK, Kim SS (1982) Chungkook-jang koji fermentation with rice straw. Korean J Food Sci Technol, 14, 301-308

31. Kim KH, Yun YS, Chun SY, Yook HS (2012) Antioxidant and antibacterial activities of grape pomace fermented by various microorganisms. J Korean Soc Food Sci Nutr, 41, 1049-1056

32. Kang DH, Kim HS (2010) Characterization and anti-Helicobacter pylori activity of Xanthium strumarium L. extract on lactic acid fermentation. KSBB, 25, 244-250

33. Kim SY, Lee HJ, Park JH, Kim RY, Cheong HS, Park EJ (2013) Effect of fermentation on the metabolic activities of pine needle juice. J Korean Soc Foof Sci Nutr, 42, 325-334

34. Jung HK, Jeong YS, Youn KS, Kim DI, Hong JH (2009) Quality characteristics of soybean paste (Doenjang) prepared with Bacillus subtilis DH3 expressing high protease levels and deep-sea water. Korean J Food Preserv, 16, 348-354

35. Cho YJ, Cha WS, Bok SK, Kim MU, Chun SS, Choi UK (2000) Production and seqaration of antihypertensive peptide during chunggugjang fermentation with Bacillus subtilis CH-1023. J Korean Soc Agric Chem Biotechnol, 43, 247-252 